\title{
Equilibrium in Ethic Economics
}

\author{
Bijan Bidabad \\ B.A., M.Sc., Ph.D., Post-Doc. \\ Professor \\ Economics and Chief Islamic Banking Advisor \\ Bank Melli, Iran \\ E-mail:bijan@bidabad.com
}

\begin{abstract}
We will study the concept of equilibrium in conventional and ethic economics in this paper. By a general review of the subject of equilibrium from basic sciences' point of view, we will study the meaning of equilibrium at different levels of micro, macro, and international economics; and by considering the lust and anger powers of human being, the concept of optimizing human behavior in Neoclassical theory will be studied. The hypothesis of "rational behavior" and philosophical and the root of thoughts and human behavior modeling in neoclassical economics will be analyzed from pleasure or utilitarianism-based point of view. By putting forward the concept of "perfection" as materializing innate power of creatures, we introduce the concept of ethic science so that we will review the correctness and goodness of actions and qualities of the human being in the process of optimizing economic behavior. Level of equilibrium in the powers as prescribed by ethic science with the meaning of preventing overindulgence and under-indulgence will be discussed. The meaning of equilibrium in ethic economics is a global optimum and in the form of utility point of view, has a broader domain of qualities and intellectualities and human being spirituals always at least is in a position that is better than Neoclassical optimized behavior (which is a local optimum).Some qualities related to economic behavior and overindulgence and under-indulgence and their equilibrium have also been considered. Equilibrium in ethic economics means using resources and locating everything in its right position and in the direction of obtaining human being perfection. Putting things in their right position is the optimal use of them from a mathematical point of view, and perfection is defined as reaching the ultimate innate of every creature. This means that in order to maximize the utility, resources should be used in a manner that in addition to ensuring human being material needs, assure the necessary background for maximizing mental and spiritual growth and elevation of him.
\end{abstract}

Keywords: Equilibrium, Ethic economics, Ethics.

\section{Introduction}

The concept of equilibrium is one of the most important analytical concepts in all scientific fields and has a value and ethical judgment touch in its preliminary and transcendental meanings. Different sciences use the concept of equilibrium in different ways, and all phenomena of the existing world are involved in this concept. The reason for the existence of this concept in all phenomena is the conflict and struggle of opposed powers the result of which is the creation of a situation which is called equilibrium; whether it is constant, or moving, stable or unstable, transitional or permanent, damping or explosive, oscillatory or non-oscillatory, short run or long run equilibriums. The various characteristics of these definitions have been studied in detail in the subject of difference and differential equations of the most basic science (mathematics) [I]. All these concepts show how the equilibrium of powers occurs. We can observe this concept in cinematic, static, and dynamic subjects of physics and specifically in mechanics. Although inertia of equilibrium is seen more in cinematic than in the two other fields, which involves movement and time, but inertia is also an achieved equilibrium. The concept of net powers in mathematical physics is analyzed by vector algebra, which is a neat and expressive analysis. Practically, vectors by describing the amount of active powers and their angles and direction of power show the equilibrium position for a mass which receives the power. This equilibrium shows the behavior of the smallest substances at the threshold between material and energy or the largest galaxy masses. Different physical theories one by one are developed and violate each other, and just describe equilibrium in another way, but equilibrium is just the result of various powers. The most important behaviors of powers in physics are the results of Newtonian rules in relation with usual and tangible physical spaces which we will not deal with here. However, in unusual spaces such as what Einstein or Heisenberg describes in the curvature of space or uncertainty in electron location (in quantum mechanics) is also a function of powers' rules too.

The same result of powers is called in human and behavioral sciences. Desires, wants, affection, love, hate, disgust, and other 
similar terms in the concept of motivations and emotions (in psychology) describe powers, some of which are attractive and others are repulsive. From theosophists' point of view, the powers inside human beings are classified into two main groups of aphrodisiac (lust) and anger. The aphrodisiac (lust) power in a human being is the power that absorbs every mild to human nature, and the anger power is that power which prevents every rough. Net of these two attractive and repulsive powers in every dimension draws the equilibrium of human being behavior. We call this equilibrium "practical equilibrium" because it is free from value contents, which are considered in the ethics discussion. The practical equilibrium describes human being behavior that is left at the middle of absorbing and repulsive powers struggle and has tried to absorb mild factors as much as he could, and repulse rough factors as much as he could.

The optimization of human being behavior comes out of this concept. It means that human being because of selfishness, tries to repulse whatever is rough and hard to him, and absorb whatever is mild and gentle to him. That is, maximize mild and gentle things and minimize rough and hard things ${ }^{\mathrm{I}}$. This description is analyzed in different ways for different behaviors. Each theory describing this concept has practically described the concept of equilibrium. In behavioral sciences, these analyses have been put forward in the framework of the result of behaviors. Norms have also been described as the result of the behavior of the majority of people of the society. That is to say, if the result of these powers has created a special behavior among the majority of the people, the society is considered and defined that behavior as a social norm and its opposite as an abnormal. Accordingly, since powers resulted from selfishness; absorbs mild and repulse rough things; therefore, the correct behavior is assumed as the behavior that maximizes absorbing mild and minimizing rough things. This behavior is called "rational behavior", which is one of the main assumptions in socio-scientific analyses of human behavior. Although this rationality is one of the most important assumptions in economic analysis, it is not much reliable in ethic economics. Theosophists consider this intellect as very poor as rational in common. This rationality is not farsighted and end-sighted and has a limited range in maximizing good things and minimizing bad things; while, the real intellect has a very wide-range in optimizing behavior. Mathematically, the comparison of these two terms describes optimization in a larger domain which is quite similar to the comparison of the local optimum and global optimum. When the shorter domain is within the larger domain, or is a subset of that, the global optimum is always better or equal to local optimum, and this is an indisputable mathematical rule. That is to say, the intellect, which can con sider more variables and horizons that are more distant, will get maximization result more or equal in comparison with the intellect or rationality that considers fewer variables and nearer horizons.

This introduction was described to check the concept of equilibrium in relation to intellect and rationality. This is because, the rationality assumption is one of the most important behavioral assumptions of neoclassical economists and that is why many economic subjects in this spectrum of theories cannot be analyzed, and we have to put forward a new framework for it. We put forward ethic economics in this direction.

\section{Equilibrium in Economics}

The concept of equilibrium has been put forward by different economists, and several theories have been described in the fields of micro, macro, and international economies. The basic concept of equilibrium in economic behaviors has an accounting infrastructure and is hidden behind simple concepts of purchase and sale, receive and pay, asset, and liability. For example, purchase of a good is equal with the sale of that good by the seller and receiving sum needs to be equal for the receiver and the payer of the opposite side and the assets of one side is equal to the claims in the other side, and debit of an item is equal to the credit of that item on the other side. Although because of repetition, these concepts look commonplace, but they are the equilibrium base of economic behavior of human being which is generalized in economics as consumer's equilibrium, producer's equilibrium, equilibrium of supply and demand, market equilibrium, equilibrium in several markets, equilibrium between money market and commodity markets, equilibrium in macroeconomics, equilibrium in global economy, equilibrium along time, and so on.

Consumer's equilibrium in neoclassical economics is obtained because of the excessive behavior of a consumer in maximizing absorption of mild things by obtaining maximum possible goods and commodities in the market. In this regard, her budget constraint does not allow her to buy all goods and services supplied in the market; therefore, she has to equalize his purchases according to her budget limit. Her behavioral equilibrium occurs in this situation, and her expenditure (disregarding her saving) will be equal to her income. In the framework created, the consumer will maximize her satisfaction by evaluating relative utilities of different goods and services in the form of a basket of goods and services she buys. We can see the details of this behavior in microeconomic theories.

\footnotetext{
I - This procedure is shown as saddle point in mathematical planning, in which the movement in longitudinal direction has a minimum at the center of saddle, and latitudinal movement has a maximum at the center of the saddle. Therefore, the centre of the saddle is at minimum from one dimension of coordinates and at maximum from the other dimension.
} 
The producer also follows a similar procedure. In order to maximize profit (in perfect competition assumptions), she maximizes her production while cost and capacity constraints do not let him produce without limits; therefore, she produces according to her resources constraints. Since the yields of various factors of production are different, she tries to combine them in such a way that maximizes her production with limited costs. Thereof, from the neoclassical point of view, equilibrium is achieved.

Meeting consumers and producers at market place causes transactions between them and the amount bought will be equal to the amount sold, which creates the concept of equilibrium in the market. The meaning of supply and demand which is the result of consumers' and producer's behaviors, causes the equilibrium price for transactions, and the rest, is the propensity to buy (for the consumer) and propensity to sell (for the producer). The market equilibrium theory is obtained from this concept, and the most important of them are described by Walras and Marshal, which show market equilibrium.

According to Walras law, if there is a positive excess demand in the market, price tends to increase, and if the excess demand is negative, price tends to decrease. Excess demand is the difference between the consumer's demand at a certain price, and the seller's tendency to supply the good to the market at that price. As it is seen in the figure below, at price $\mathrm{P}^{\prime}$ excess demand is positive and equal to $\mathrm{A}^{\prime} \mathrm{B}^{\prime}\left(=\mathrm{a}^{\prime} \mathrm{b}^{\prime}\right)$. At price $\mathrm{P}^{\prime \prime}$ the excess demand is negative and is equal to $\mathrm{A}^{\prime \prime} \mathrm{B}^{\prime \prime}\left(=\mathrm{a} " \mathrm{~b}^{\prime \prime}\right)$. The excess demand at this price in these conditions is the difference between the price at which consumers are willing to pay and the price at which producers are willing to sell the goods at the market.

In Walras theory, when excess demand is positive (negative), buyers (sellers) who have not been able to buy goods, will increase (decrease) the price. If price increase (decrease) which is because of positive (negative) excess demand, the standing equilibrium will decrease (increase) the excess demand. That is to say, if:

$$
\frac{d E(p)}{d p}=\frac{d[D(p)-S(p)]}{d p}<0, \quad \frac{d D}{d p}-\frac{d S}{d p}<0
$$

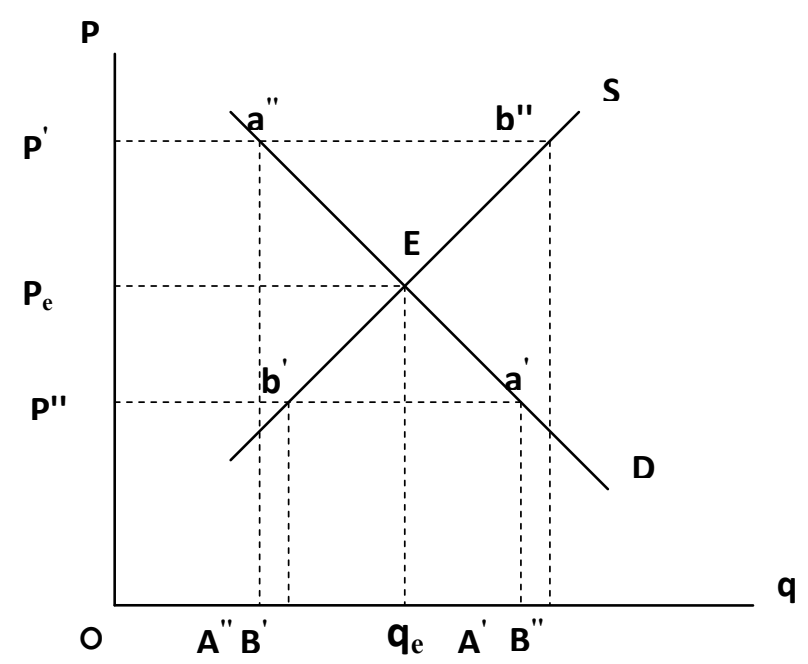

Walras Equilibrium

According to Marshal's assumptions, the quantity will tend to increase (decrease) if excess demand price is positive (negative). Excess demand price is the difference between the price at which buyers are willing to buy a certain amount of good, and the price at which sellers are ready to sell the same amount of good. This is shown in the figure below. According to this figure, the amount of $\mathrm{q}^{\prime}$ is the excess positive demand price equal to $\mathrm{A}^{\prime} \mathrm{B}^{\prime}=\left(\mathrm{a}^{\prime} \mathrm{b}^{\prime}\right)$ and in $\mathrm{q}^{\prime \prime}$ excess demand price is negative and equal to $\mathrm{A}^{\prime \prime} \mathrm{B} "(=\mathrm{a} " \mathrm{~b} ")$.

In Marshal view, equilibrium is created when the increase (decrease) of quantity, which is because of positive (negative) excess demand price, decreases (increases) the excess demand price. That is to say if:

$$
\frac{d E^{-1}}{d q}=\frac{d\left[P_{d}(q)-P_{s}(q)\right.}{d q}\left\langle 0, \quad \frac{d p_{d}}{d p}-\frac{d p_{s}}{d q}\langle 0\right.
$$


Or, since $\mathrm{pd}_{\mathrm{d}}=\mathrm{pd}_{\mathrm{d}}(\mathrm{q})$ is the invers function of $\mathrm{D}=\mathrm{D}(\mathrm{p})$ and $\mathrm{p}_{\mathrm{s}}=\mathrm{p}_{\mathrm{s}}(\mathrm{q})$ is the inverse function of $\mathrm{S}=\mathrm{S}(\mathrm{p})$, we will have:

$$
\frac{d p_{d}}{d q}=\left(\frac{d D}{d p}\right)^{-1}, \quad \frac{d p_{s}}{d q}=\left(\frac{d S}{d p}\right)^{-1}
$$

Therefore, the above inequality will become like the following inequality, and Marshal's assumptions will be:

$$
\left(\frac{d D}{d p}\right)^{-1}-\left(\frac{d S}{d p}\right)^{-1}<0
$$

Equilibrium is transferred from one market to another. In other words, we have to say that the markets simultaneously find equilibrium in the economy. If there is equilibrium in a market, another market must be in equilibrium too. This is from several markets equilibrium concept from Walras point of view, which nicely explained multi-market equilibrium in the economy. Regarding disequilibrium, it should be mentioned that this concept is an abstract and theoretical concept in microeconomics and is shaped because of inventory change. In addition to this, in macroeconomics, it includes statistical discrepancies.

Irving Fisher nicely dragged the equilibrium concept from microeconomics to the equilibrium in monetary and commodity markets. In his book [13], Fisher used figures such as sea-saw and balance, to relate two concepts of goods and money and invented "quantity theory of money". This theory uses simple physics rules to make similarity of equilibrium in money and commodity markets and by using several examples; he describes the relationship between two markets and their equilibrium. His theory is important because equal to the amount of transactions in the commodity market; money should be paid (received) in the money market. This concept which looks quite simple, has so much importance that if we say equilibrium theory of Walras

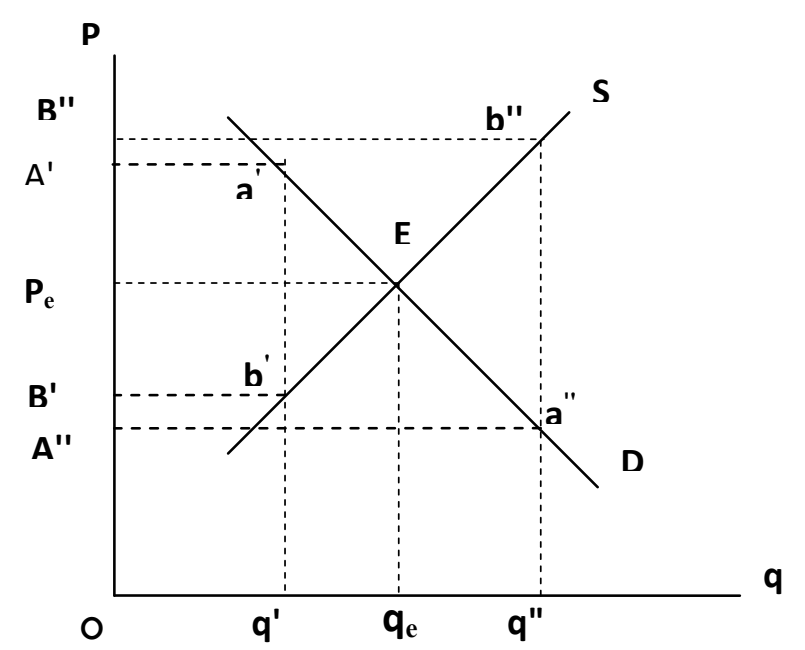

(in microeconomics) and Fisher equilibrium theory (in macroeconomics) and trade equilibrium theory of Ricardo have been so important that other theories do not shine so much in front of their theories in economic thought history, we have not said wrong. Perhaps these three economic theories are at the same level of importance of the important theories of Newton (law of inverse of squared distances), Planck relation and Einstein kinetic energy theories in physic.

Ricardo dragged the equilibrium concept to foreign markets and studied the equilibrium among countries from a trade point of view and generalizes it to global equilibrium. That is to say, global imports are equal to global exports, and if the trade balance of a country is positive, it will be negative in another country or some other countries. Theories such as "monetary approach to 
the balance of payment" are complementary to this theory regarding the flow of foreign exchange payments and receipts.

Practically, introducing time into equilibrium concept dynamized the analysis and made it possible to transfer equilibrium from a time period to another. The concept of "inter-temporal" studied the human being behaviors in optimizing her utility or profit regarding postponing consumption and making saving and also making fixed capital formation for production in later periods and optimum behavior along the time which is another description of equilibrium by considering time.

\section{Philosophical Base of Equilibrium in Economy}

Before starting a discussion about ethic economics, we'd better mention that the root of thoughts and behavioral modeling of a human being in neoclassical economics comes from the philosophy called "Hedonism school of thought" or "Utilitarianism" [I4] which considers the measure of being ethical as hedonism. Since ancient Greece till the temporary days, hedonism has been described in several ways such as Aristippus individual hedonism, Epicure limited individual hedonism, Jeremy Bentham and John Stuart Mill hedonism in public utility, Adam Smith sentiment hedonism, and hedonism in activism by Bertrand Russell.

Although the similarities of these schools of thoughts, they have delicate differences in various economic theories. Most of these views have been documented by mathematical tools in neoclassical consumer theory.

Socrates believed that human being is seeking pleasure and salvation, and has no other duty, but pleasure is not achieved through satisfaction and lust, whenever be prevented from bodily desires [2]. Aristippus ${ }^{2}$ (435BC-366BC) in spite of Socrates, said human being should listen to her natural call, and find out if that work is welcomed by his nature or not. If it is welcomed, she should do it, and if it is not, she should stop it. In other words, if the work is mild to her nature and creates pleasure, it is good, and if it is rough and against individual nature, she should stop doing that.

Epicure $^{3}$ (34IBC-27IBC) also put forward hedonism. He considered continued relaxation and comfort rather than short and lusty pleasure. He said a wise man prefers spiritual pleasure to material enjoyments [2]. Principally, in spite of Aristippus theory, he has introduced wisdom and intellect in limiting pleasure and confines it in the framework of wisdom. The result is that he introduces a life in which wisdom influences pleasure and mental pleasures are superior to bodily pleasures. In other words, he asked for ethical pleasure.

Jeremy Bentham (I832-I848) and John Stuart Mill (I806-I873) put forward the school of public or, the social interest which considers social profit. They have replaced individual hedonism with public or social hedonism and have changed ethical action of individual enjoyment to social enjoyment. The legitimacy of action is implemented in enjoyment and salvation of the community and truthfulness of action is the result of it, not the cause of it, and if an individual tries for public benefit, his own benefit will also be achieved. Mill's formulated utilitarianism as the "greatest-happiness principle". It holds that one must always act so as to create the greatest happiness for the greatest number of people in society. Bentham treats all forms of happiness as equal, whereas Mill argues that intellectual and moral pleasures are superior to more physical forms of pleasure. Mill distinguishes between happiness and contentment, claiming that the former is of higher value than the latter.

The motivation for action in the school of sentimentalism is humanistic feelings, which persuaded him to do that work. Adam Smith (1723-I790) and Arthur Schopenhauer (I798-I857) and Auguste Comte (I798-I857) have described humanistic feelings as the cause and even the ultimate goal of the action. They say the work based upon "selfishness" is not ethical and only the work with humanistic goals is ethical, not with the aim of selfishness.

Bertrand Russell (I872-I970) put forward the coordination theory of individual benefits and public benefits. The top ethical items of his theory are the establishment of coordination between the individual and public benefits ${ }^{4}$. He believes that if the action does not cause losses to others, we have no reason to condemn that action ${ }^{5}$.

\section{Ethic and Perfection}

Before entering into the subject of equilibrium in ethic economics, we will have a glance at the definition of perfection and its relation to ethics. The perfection of every creature is implementing his natural power from potency to action. In other words, the ultimate goal of the existence of any being is her perfection. The special characteristic of a human being is the power of her intellect, and his perfection is hidden in the perfection of his intellect. The perfection of a society depends on the perfection of

\footnotetext{
2 - Aristippus was a disciple of Socrates and lived at the time of Plato (347-428 bc).

3 - Borne $34 \mathrm{I} \mathrm{bc}$ and lived for 70 years.

${ }^{4}$-Bertrand Russell Speaks His Mind, 1960, Farsi translation, Amirkabir Publishing, I345, Tehran, pp 64-65.

${ }^{5}$ - Bertrand Russell Speaks His Mind, 1960, Farsi translation, Amirkabir Publishing, I345, Tehran, p 68.
} 
each member of that society, in a way that their composition or union creates the most perfect situation. This means that if we divide perfection to individual and social perfections, the individual perfection alone is not equal with her perfection in the society. The body is a chariot for the soul and is at the service of a human being to flourish her talents with the help of her spirit until she dies. Therefore, a healthy body is not the ultimate goal, because the perfection of the human being is not the perfection of his body 6 .

Ethic science discusses the truthiness and goodness of human being actions and features. Different ethical schools of thoughts, introduce different measures for goodness and badness of actions, but by considering the above discussion, we can say that any action helping human being perfection is good and true, and those actions which endanger his perfection is wrong and bad. Also, for diagnosing the qualities, we should see which one is implementing the ultimate perfection of human being, and which prevents it. That is to say, any quality which makes her perfection possible is an excellence and what prevents it, is a Knavery.

About ethics in "Pand-e-Saleh" treatise [I], it is written: "The human being is composed of all the characteristics attributed to animals but which are more perfectly created in man in order that he might endeavor, like them, to seek what is good or bad as well as what is of benefit or of detriment to his body, so that he might gain in comfort and repel that which might cause damage and pain. Besides, man has the faculty of thought and reason by which he can keep all attributes at a moderate level, gain domination over his lower soul (nafs), employ them for the advancement of his spirit, and reveal praiseworthy morals in himself, avoiding those that are blameworthy. Therefore, the believer should always be attentive to the correction of his soul and the refinement of his inner morals, because the "spiritual fixed habits", which compel a man to action, if they be praiseworthy, will produce good deeds and if they be blameworthy, will produce evil deeds. Although ethicists have explained these things in detail in their books and have given instructions about them, by reading moral books, even the Traditions (ahadith) and the Qur'an, a person cannot gain praiseworthy qualities thereby. For as soon as one head of the lower soul is struck down, it raises another head. Thus, the struggle against the lower soul and Satan should be down resolutely, with the attractive force of eagerness (shawq) and live arising from Faith. It should be done by appealing to the inner being (batin) of the Saints and asking their help as well as by watering the subtle essence (latifa) of walayat, which is present in the hearts of the Faithful. This subtle essence is the "dignity of the most supreme spiritual reality of 'Ali" ('alawiyyat-i 'Ali-peace be upon him), which draws the believer constantly from the darkness of ignorance and the world of nature into the light of incorporeality (tajarrud) and Knowledge. And there is no other causative agent in the world but it: "La fata illa 'Ali" (there is no chevalier spiritually but 'Ali). Therefore, within the Dhulfaqar of invocation (dhikr) and meditation (fikr), which is granted to him, he should lay an ax to the root of the lower soul; and so dedicate the dependence and intimacy of the lower soul; and so dedicate the dependence and intimacy of his heart to the remembrance (dhikr) of God that the fondness of the world - which is born out of egotism and obstinacy and is the root of all sin and the source of all indecency - might gradually decline. Thus, he might gain domination over the lower soul and be able to prevent its manifestations until it is non-existent. Unless such a state is attained, Mawla's approval by which moral virtues are measured will not be achieved. For one's duties and behavior differ according to different cases: in one case, He approves of our being hard and in another case of our being merciful. And moderation cannot be determined by Imperfect reason or a low intelligence, unless the heart becomes the seat of God and the Truth rules over the heart which of itself rules over the body."

Tabatabaee [7] believes that the essence of a human being is a mixture of three powers of lust, anger and thought from which have made a compound unity, and special actions are issued by them, actions which are not seen in any other creatures. Therefore, it is obligatory for her to prevent each of these powers from overindulgence or under-indulgence and not to deviate from the middle line, because if one of these powers deviate, the human being compound will lose its quality and therefore, will not reach to its ultimate goal for which he has been compounded for.

The balance between these powers is to use them in their right place, from a quantitative point of view, as well as a qualitative point of view. This means prevention of overindulgence as well as under-indulgence as it was mentioned.

In defining ethic science, Naraghi says: "ethic science is the science of savior and fatal qualities and the method of being characterized with savior characteristics and freedom from fatal ones." A Allameh Tabatabai has also a similar definition of ethics $^{8}$, which means Islamic ethic is decorating human being essence with admirable tempers. Jacques believes ethical science is the implementation of human being behavior in a way that it should be ${ }^{9}$. This definition coincides exactly with the definition of justice, which means putting things in a place that it should be.

\footnotetext{
6 - Look through: Fathikhani, Mohammad, “Amouzehaye bonyadin-e- elme akhlagh”, vol. I.

7 - Naraghi, Mohammad Mehdi, Jame Al-Saadat, PP. 34-35.

8 - Tafsir Al-Mizan, Vol. I, P. 376.

9 - Jacques, Falsafeh Akhlagh, Hekmat-e- Amali, translated by Pour Hussaini, 2 ${ }^{\text {nd }}$ edition, Amirkabir Publications, Tehran, 1983 , p 18.
} 


\section{Equilibrium in Ethic Economics}

The meaning of equilibrium also results from the same discussion. Economic affairs are not targeted in human life by Islam, but it was considered a necessary tool by which ethical and spiritual excellence is reckoned. Islam invitation is to observe moderation is in these affairs. That is, observing moderation in spiritual as well as material affairs. For example, even regarding charity, which is the result of ethics, Islam has commented to do moderately. The Quran in characterizing divine believers commands: "they are those who do not squander or thrift in charity, but they do it moderately" I0. The terms of "squandering" and "thrift" which are opposite of each other in this verse, have the same meaning of overindulgence and under-indulgence. Squandering or overindulgence means using more than limits and un-right and unjust, and thriftiness means using less than needs and right and just. In another verse, he commands: "never chain your hand to your neck (don't abandon charity) and do not open it more than limits, so that you are not blamed and are not disabled" ${ }^{\text {.1 }}$. Regarding equilibrium in economic behavior, which is resulted from this moderation, the Quran commands: "O thou! Those who are believers, do not regard unlawful the clean blessings which God has made lawful for you, but don't exceed the limit; because God does not like who have exceeded limit" I2.

This equilibrium does not mean monastic life. It is commanded: "manage the world tasks so that you live forever and manage the tasks of the afterlife in a way that you are going to die the next day" ${ }^{13}$. Ali (peace be upon him) says: "O thou! God's believers, you should know the righteous people have gained the goodness of world and afterlife; they shared their world with people, but the people do not share at their afterlife. God allowed the world to them according to their needs. They lived much better in the world with many blessings. They shared the world of world-possessors, and enjoyed from the best foods and drinks and enjoyed life, while they were considering their afterlife too. Their wishes will be granted to them in the other world. Their requests will be answered, and their pleasures will not be undermined. Those who have wisdom and virtue will willingly move towards this direction" ${ }^{14}$.

As it is understood from the discussion above, the maximization behaviors of consumer's utility and producer's profit are the behaviors which maximize the absorption of good and mild things - from the ethics science point of view - and as discussed before, this behavior is induced by lust power which tries to absorb mild things. If we accept the rationality assumption as described by neoclassical economists, mathematically, these behaviors will reach their optimism (ceteris paribus). But this optimum is local from the "ethic economics" point of view, because the domain in ethic economics is wider than the domain of neoclassic economics. Because, peace and transcendence, elevation, humanity, non-material love, spiritualities, altruism, worship, self- sacrifice, indulgence, sincerity... dimensions are not denied in neoclassic view, but are not considered. In other words, the characteristics of human behavior can be introduced into the economic behavior of the neoclassic theory, which has not been implemented in the latter. Although it is said that economics is a material and non-spiritual subject; but ethic economics is looking for to consider all material economic discussions for the material and spiritual elevation of human beings; and not just her material comfort.

Here we name some of the qualities of human beings in relation to her economic behavior; some of them are agreeable some are disagreeable, but the optimum behavior from ethic economics point of view is moderation and balance between them. Overindulgence and under-indulgence locate at both sides of moderation and the most important economic behaviors locate under the topics of squandering, thriftiness, and moderation. Over-consumption and stinginess are also two extremes, and moderation in spending is in between the two. Hoarding (accumulating wealth, gold and treasure) is the opposite of extravagance, and moderation with traditional economic meaning (the science of subsistence) is in between them. Proudness, because of assets is overindulgence and carelessness to keeping wealth and assets up under-indulgence and keeping up the properties is the moderation. Financial circumspect and pass-out are two sides of overindulgence and under-indulgence and leaving the wishes and confronting with reality is moderation. Amplifying the assets is overindulgence and its opposite is wasting the properties is under-indulgence and balanced growth of wealth is moderation. Subsistence moderation is between wealth and poverty, and greed, covetousness, avarice, avidity and cupidity are at overindulgence extreme and carelessness and negligence are at the opposite extreme as under-indulgence; and their moderation is contentment. Lavishness is opposite to abstinence and monastic, and caring the vale according to needs is at their moderation. Hardworking is the opposite of laziness and working and the balance between them is moderation. Jealousy and regret to others are two extremes and emulation and warning is moderation. Luxury and loving ornaments are opposites of rags clothed and cleanliness is the moderation. Thriftiness, meanness, miserliness, sordidness and vileness are at one side and wasting and throwing away and garbaging are the opposite side and

\footnotetext{
I0 - Forghan surah, verse No. 67,

II - Asraa surah, verse No. 29,

${ }^{12}$ - Maaedeh surah, verse No. 87,

${ }^{13}$ - Baphr Al Anvar, Vol No. 139, p 44,

${ }^{14}$ - Tafsir Al Safi, vol No. 2, p I93,
} 
consuming enough and safeguarding property is its moderation. Optimism and pessimism are the two extremes which are on the two sides of confidence. Cheating and being cheated are to extremes of transaction. Many other good qualities such as nourishing the poor, self-sacrifice, charity payment, generosity, honoring, safe custody, sociability, gentlemanly, giving generously, removing poverty, and ... are on the opposite side of disagreeable actions such as shortchanging, overcharging, selfinterest, cheating, speculating, deception, fraud and dishonesty, and...

All these considerations have been neglected in neoclassic economics; therefore, the optimum in neoclassical economics is a local optimum, not a global. Definitions in ethic economics should be different from conventional economics. Therefore, the concept of equilibrium (or moderation) in addition to material characteristics which we discussed, should include equilibrium characteristics, meaning being at the middle and justice (meaning: "putting thing at its right position") and if we add the goal of transcendence of human being spirit, the meaning of equilibrium in ethic economics is to put things in their right positions and achieve maximum growth and elevation of human being or the fulfillment of human being perfection. Putting things in their right positions mathematically means optimized use of them. Fulfillment of perfection means to make human being innate power practiced. Certainly, this growth and elevation is material as well as spiritual. That is to say; resources should be used for maximizing uses (utility/production) in a way which in addition to satisfying material needs of human being, create the background for maximizing mental and spiritual growth and elevation of the human being.

\section{References}

[I] His Excellency Hajj Sheikh Mohammad Hassan Bidokhti Gonabadi Salehalishah, "Pand-e Saleh”, Haghighat Publications. 1938. Reprinted: 2014. http://www.sufism.ir/pandesaleh.php

[2] Tabatabaee Allameh Seyyed Mohammad Husain, Al Mizan fi Tafsirel Quran. Islamic Publication, Qom, 1997.

[3] Allameh Tabatabaee Seyyed Mohammad Husain, Al MIzan. Farsi translation. Al Mizan fi Tafsirel Quran. Islamic Publication, Qom, 1997.

[4] Bertrand Russell, Bertrand Russell Speaks His Mind, I960, Farsi translation, Amirkabir Publishing, I966, Tehran.

[5] Bidabad Bijan, Difference equation theory and dynamic stability of equilibrium. 2005. http://www.bidabad.com/doc/difference-equations.pdf

[6] Fat'h-aliKhani, Mohammad, Amouzehhaye Bonyadin-e- Elme-e-Akhlagh, 4 volumes. Bashgahe Andishe Publication. http://www.irpdf.com/book-3709.html

[7] Feiz-e-Kashani, Mullah Mohsen, Tafsire Alsafi. Sarol-Kotob Islamiyah, Tehran, 1989.

[8] Fisher, Irving, Purchasing Power of Money, I9I I, Macmillan Publication.

[9] Foroughi, Mohammad Ali, Sair-e- Hekmat in Europe. Jibi Publication, I94I.

[IO] http://www.utilitarianism.com/

[II] Jauques, Falsafeh Akhlagh, Hekmat-e-Amali, translated by Pour Hussaini, $2^{\text {nd }}$ edition, Amir Kabir Pub., Tehran, 1983.

[I2] Majlesi, Mohammad Bagher, Behar Al Anvar. In IIO Volumes. I696. http://majlesi.net/

[13] Naraghi Mohammad Mehdi, Jame-o-Saadat. Translated to Persian by Jalaledin Mojtabavi, Hekmat Publications, I998.

[I4] Richard Popkin; Aurom Stroll, Generalities of Philosophy, translated by: Mojtabavi, Jalaledin, I975, Tehran.

\section{Copyrights}

Copyright for this article is retained by the author(s), with first publication rights granted to the journal. This is an open-access article distributed under the terms and conditions of the Creative Commons Attribution license (http://creativecommons.org/licenses/by/4.0/). 